IRA-International Journal of Management \& Social Sciences

ISSN 2455-2267; Vol.12, Issue 02 (August 2018)

Pg. no. 49-54.

Institute of Research Advances

http://research-advances.org/index.php/RAJMSS

\title{
Adapting Agriculture to Climate Change: Do Floods Affect Cropping Intensity? Evidence from a Flood Prone District in Assam, India
}

\author{
Rupon Basumatary $\mathrm{PhD}$ \\ Department of Economics, Cotton University, Guwahati, Assam, India.
}

Type of Review: Peer Reviewed.

DOl: http://dx.doi.org/10.21013/jmss.v12.n2.p5

\section{How to cite this paper:}

Basumatary, R. (2018). Adapting Agriculture to Climate Change: Do Floods Affect Cropping Intensity? Evidence from a Flood Prone District in Assam, India. IRA-International Journal of Management \& Social Sciences (ISSN 2455-2267), 12(2), 49-54. doi:http://dx.doi.org/10.21013/jmss.v12.n2.p5

(C) Institute of Research Advances.

\section{(cc) $\mathrm{BY}-\mathrm{NC}$}

This work is licensed under a Creative Commons Attribution-Non Commercial 4.0 International License subject to proper citation to the publication source of the work.

Disclaimer: The scholarly papers as reviewed and published by the Institute of Research Advances (IRA) are the views and opinions of their respective authors and are not the views or opinions of the IRA. The IRA disclaims of any harm or loss caused due to the published content to any party.

Institute of Research Advances is an institutional publisher member of Publishers International Linking Association Inc. (PILA-CrossRef), USA. The institute is an institutional signatory to the Budapest Open Access Initiative, Hungary advocating the open access of scientific and scholarly knowledge. The Institute is a registered content provider under Open Access Initiative Protocol for Metadata Harvesting (OA/PMH).

The journal is indexed \& included in WorldCat Discovery Service (USA), CrossRef Metadata Search (USA), WorldCat (USA), OCLC (USA), Open J-Gate (India), EZB (Germany) Scilit (Switzerland), Airiti (China), Bielefeld Academic Search Engine (BASE) of Bielefeld University, Germany, PKP Index of Simon Fraser University, Canada. 


\begin{abstract}
Empirical studies that have recently built up in stock particularly with the growing awareness about the climate change since the 1970s show that people's agricultural activities are disastrously affected, among others, by natural calamities of which floods are the most common hazards that the farming populations in particular have ever confronted with across the world. Their adverse effects are further expected to escalate with the present pace of global climate change, making it necessary to devise suitable adaptation measures for sustainable agriculture. Given these premises, the present study based in one frequently flood hit district of Dhemaji in the state of Assam, India, makes an attempt to examine whether cropping intensity of the cultivator households is affected by their flood proneness. Ordinary least square estimation result shows that the cultivator households in flood prone areas have statistically higher cropping intensity compared to the flood free households. This, however, does not in any way predict higher agricultural production or productivity by the flood prone farmers. The results, on the contrary, implicitly prescribe for a comprehensive agricultural policy particularly designed for flood prone areas, enveloping strategies but not limited to suitable irrigation infrastructure, mass awareness for productive agricultural practices, subsidised seeds and other inputs, and post harvest agriculture infrastructures including marketing facilities.
\end{abstract}

Keywords: Dhemaji, cropping intensity, agriculture, floods

\title{
Introduction
}

Climate change and variability are among the most crucial challenges facing the least developed countries because of their strong economic reliance on natural resources and rain-fed agriculture (FAO, 2007). Agriculture sector is highly vulnerable to climate change that affects the productivity and sustainability of the sector in a multitude of ways. According to the UNDP Human Development Report 2007/08, the greatest threat posed by climate change is that of a collapse in agricultural production systems. Nelson et al (2009) pointed out that South Asia will be particularly hard hit by climate changes in terms of yield of most important crops, and that declining availability of calorie will increase child malnutrition by $20 \%$ relative to a world with no climate change. A climate change impact assessment by Inter-Governmental Panel on Climate Change (IPCC) in Africa reveals that agricultural production is severely compromised due to loss of land, shorter growing seasons and more uncertainty about what and when to plant. It is projected that by 2020 , yields from rain fed crops could be halved in some countries and, by 2100 net revenues from crops could fall by 90 percent. The assessment also predicted a general decline in most subsistence crops such as sorghum in Sudan, Ethiopia, Eritrea and Zambia; maize in Ghana; millet in Sudan; and groundnuts in Gambia (FAO, 2008).

With a finite spatial space, an increased productivity in agriculture sector is a necessity to feed the growing number of mouths. Food and Agriculture Organization (FAO) of the UN has predicted that the world has to double its food production by the year 2050 to feed its growing population. The nature and magnitude of climate change that the world is experiencing primarily since in the late 1970s, on the contrary, is likely to hold back the performance of this sector. Notably, agriculture in the developing countries is worse hit than it is in the developed countries (Nelson et. al, 2009) which has significant implications to people's livelihoods in these countries. Since a large proportion of their populations earn their livelihoods from agriculture, climate change is expected to cluster the major portion of world's poor in the developing countries (Charles, 2011). Given these potential impacts of climate change, adaptation of agriculture to climate change is a need of the hour. Studies show that many of the agricultural adaptation measures are particularly effective in moderate climate change; there are, however, limits to their effectiveness under severe climate change conditions (Howden et. al, 2007).

Floods are the most common nature hazards across the world. Further, climate change is projected to worsen the flood problems in the days to come and is likely to be a major factor in riverine, pluvial and coastal flooding (WHO, 2002). Climate change has led to the rise in sea level and it, in turn, is projected to have an adverse effect on the low lying lands and river deltas in flood prone areas. Given these propositions, the flood affected areas can be expected to differ from the flood free areas in terms of their agricultural activities in many aspects. In this paper, the researcher is limited to only understanding the cropping intensity of the flood prone vis-à-vis flood free cultivator households, based on a household level data collected from a severely flood-hit district of Dhemaji in a northeastern state of Assam, India.

\section{Contextualizing the Study}

The Asia continent, and in particular the temperate and tropical Asia, is expected to suffer the most from climate change and the resulting floods, both in terms of frequency and duration (Calder \& Aylward, 2006; Bhattacharyya \& Werz, 2012). These areas include the Hindu Kush Himalayan (HKH) Region in general and the Ganges - Brahmaputra - Meghna (GBM) in particular. It is pointed out that the eastern Himalayan countries 
- Bangladesh, India, Nepal and Bhutan - are likely to be particularly affected. The Hindu Kush Himalayan $(\mathrm{HKH})$ region countries have already been periodically experiencing major losses and damages by floods, and they may face yet more hazardous and frequent floods than up to now (Dekens \& Eriksson, 2009).

Assam, one of the north-eastern states of India in the Himalayan foothills, has a long history of being affected by annual flooding, which paralyses people's normal life in many of its districts almost every year. The Dhemaji district, which is the area of the present study, is one of these severely flood-hit districts in Assam. This district is bordered with the Indian state of Arunachal Pradesh on the north and the east, and lies on the north bank of the Brahmaputra River. Geographically, the district is in the upper Brahmaputra valley and in the eastern Himalayan Zone. According to Assam Flood Hazard Atlas (2011), flood hazard area constitutes $46.50 \%$ of the total land areas of the district. Besides the two big rivers - the Brahmaputra and the Subansiri - the district is run through by many tributary rivers, which add to the magnitude and duration of floods in the district. In particular, floods have devastating effects on the lives of farming households in the district who, as per the Population Census (2011), constitute about $80 \%$ of the district population. With weak industrial bases characterized by the absences of any big or medium scale industries to provide employment it becomes necessary to adapt people's agricultural activities to the pace nature of climate changes. However, while cropping intensity can in no way reflect the kinds of adaptation people choose for, it can at least act as a barometer of farming people's efforts or lack thereof against the perceived climatological risks. The present work is therefore subject to this limitation of non-inclusion of a multitude of adaptation strategies, but focusing indirectly on cropping intensity as a proxy for them.

\section{Data and Methods}

\section{Data}

This study is based on a sample of 163 cultivator households that belong to two non-contagious groups in terms of their flood proneness or flood effects - (a) 124 flood prone cultivator households drawn from ten 'floodprone' villages, and (b) 39 cultivator households drawn from three carefully selected flood free villages. Multistage sampling technique has been used for collecting data at the household level. A pre-tested household level questionnaire has been used to collect the required data for the purpose.

Tool for Analysis: Linear regression has been carried out to find the determinants of cropping intensity of the cultivator households. The primary interest in this regression is to see whether flood prone cultivator households significantly differ from the flood free cultivator households in terms of their cropping intensity. Besides, based on available literature and data from the survey, a number of other possible determinants have been included in the regression model. The model has been estimated using ordinary least squares (OLS) estimation method. Relevant tests have been conducted to ensure that necessary assumptions are satisfied.

The dependent variable here is the 'cropping intensity', which, for the present study, has been used as a proxy for intensity of land utilisation. The value of 'cropping intensity' is calculated by taking ratio of a household's Gross Cropped Area (GCA) to Net Sown Area (NSA). Cropping intensity can be expressed in percentage, and, by definition, it may exceed 100 . Higher the value of cropping intensity higher the intensity of use of farm land. 'Farm size' or 'operational holding', in this study, has been used to mean own farm land exclusive of leased-in land, if any.

The dependent variable here is continuous, while the predictor variables are both continuous and categorical. Theoretically, assuming $y_{i}$ as a dependent variable and $\boldsymbol{x}_{\boldsymbol{i}}^{\prime}$ as a vector of predictor variables for the $i^{\text {th }}$ observation and $\boldsymbol{\beta}$ as a vector of unknown parameters, the multiple linear regression model can be written as-

$$
\mathrm{y}_{\mathrm{i}}=\mathbf{x}_{\mathbf{i}}^{\prime} \boldsymbol{\beta}+\mathrm{u}_{\mathrm{i}}
$$

The basic assumptions underlying this model are - (a) normality of the error term $u_{i}$, (b) homoscedasticity of $u_{\mathrm{i}}$ i.e. $E\left(u_{i}^{2}\right)=\sigma^{2}$ (c) no autocorrelation $E\left(u_{i} u_{j}\right)=0$ (d) zero conditional mean of the error term $E\left(u_{i} \mid x_{i}\right)=$ 0 (e) no high multicollinearity among predictor variables, and (f) non-stochastic regressors $E\left(u_{i} x_{i}\right)=0$. The predictor variables in the $\mathbf{x}_{\mathbf{i}}^{\prime}$ vector drawn from the existing literatures are presented in Table 2 along with their expected direction of relationship to the dependent variable i.e. to 'cropping intensity'. The descriptive summary of variables has also been presented in Table 2. The variable values, as seen from the table, are found to be within the defined scale of measurement, and hence consistent in this regard. Given the possible determinants as explanatory variables, the regression model for the present study is fitted as: 
Log(Cropping Intensity)

$$
\begin{aligned}
& =\beta_{1}+\beta_{2} \text { FPHD }_{\mathrm{i}}+\beta_{3} \text { DEP }_{\mathrm{i}}+\beta_{4} \mathrm{HS}_{\mathrm{i}}+\beta_{5} \mathrm{FS}_{\mathrm{i}}+\beta_{6} \mathrm{HI}_{-} \mathrm{EDU}_{\mathrm{i}}+\beta_{7} \text { FARM }_{\mathrm{i}}+\beta_{8} \text { SHARE_CROP }_{\mathrm{i}} \\
& +\mathrm{u}_{\mathrm{i}}
\end{aligned}
$$

Where, the variables of the model are defined as:

FPHD: $\quad$ Dummy for flood proneness: 1 if the household is a flood prone household, and 0 otherwise

DEP : Dependency Ratio

HS : Household Size

HI_EDU: $\quad$ Highest level of education attained by any member in the household. Education is coded as: 0 = illiterate, $1=$ completed primary schooling, $2=$ matriculate, $3=$ completed the $12^{\text {th }}$ standard, $4=$ completed bachelor's degree, $5=$ post-graduation and above

FS : $\quad$ Farm Size (i.e. the size of operational landholdings in bigha, with 1 bigha $=1440$ sq. ft.)

FARM : Dummy variable for principally farming household, which takes on value 1 if the household is a principally farming household and 0 otherwise. A principally farming household is defined as the one whose all members in the active age group (15-64 years) take up farming as their principal occupation.

SHARE-CROP: Dummy for Share-cropping. It takes on value 1 if the household did only sharecropping in the preceding season, and 0 otherwise.

Table 2: Descriptive Summary of Variables used in regression

\begin{tabular}{|l|c|c|c|c|c|}
\hline \multicolumn{1}{|c|}{ Variable Definition } & $\begin{array}{c}\text { Expected Coefficient } \\
\text { Sign }\end{array}$ & Mean & $\begin{array}{c}\text { Std. } \\
\text { Dev. }\end{array}$ & Min & Max \\
\hline FPHD (dummy) & $+/-$ & 0.76 & 0.42 & 0 & 1 \\
\hline DEP (Continuous) & $+/-$ & .61 & .61 & 0 & 4 \\
\hline HS (Continuous) & + & 5.55 & 2.12 & 2 & 14 \\
\hline FS (Continuous) & - & 5.87 & 5.28 & 0 & 26 \\
\hline HI_EDU (Differentiated) & $+/-$ & 2.03 & 1.19 & 0 & 5 \\
\hline FARM (dummy) & + & 0.57 & 0.49 & 0 & 1 \\
\hline SHARE_CROP (Dummy) & - & 0.11 & 0.32 & 0 & 1 \\
\hline
\end{tabular}

Source: Author's calculation from the field survey data

\section{Results and Discussion}

Cropping intensity of the households

Cropping intensities of the cultivator households have been produced in Table-1. The Table shows that in floodprone areas majority of the cultivators (69.35\%) have cropping intensity between 100-200, while another $20.16 \%$ cultivators have cropping intensity in the range of 200-300. As for flood free areas, the corresponding figures of households are $89.74 \%$ and $5.13 \%$ respectively. Statistically, the proportions of cultivators in the cropping intensity range of 100-200 and 200-300 are different for these two household groups: while the proportion is larger for 'flood free' areas for the range of 100-200, it is larger for 'flood prone' area for the higher range of 200-300. For cropping intensity ranges higher than 200-300 as given in the table, the two household groups do not differ from each other.

Table-1: Cultivator Households by Cropping Intensity (\%)

\begin{tabular}{|c|c|c|c|}
\hline Cropping Intensity & $\begin{array}{c}\text { Flood Prone } \\
\text { Households }\end{array}$ & Flood Free Households $^{\#}$ & $\begin{array}{c}\text { Significance of } \\
\text { difference }\end{array}$ \\
\hline $100-200$ & $69.35 \%$ & $89.74 \%$ & $* *$ \\
\hline $200-300$ & $20.16 \%$ & $5.13 \%$ & $* *$ \\
\hline $300-400$ & $5.65 \%$ & NIL & NS \\
\hline 400 and above & $4.84 \%$ & $5.13 \%$ & NS \\
\hline Total & $124(100 \%)$ & $39(100 \%)$ & - \\
\hline
\end{tabular}

Source: Author's calculation from the field survey data

Note: Cropping intensity has been calculated for cultivator households; *, **, *** respectively mean 
significant at $10 \%, 5 \%$ and $1 \%$ level; NS = Not significant; Significance reported for two-tailed test.

\section{Regression Results: Discussion}

In order to identify the determinants of farming households' cropping intensity and to examine whether 'floodproneness' significantly influences it, an OLS regression has been conducted. However, usual OLS could not be run on the absolute values of Cropping Intensity (CI) as the data did not satisfy the distributional assumption of the model, namely normality. Thus, in order to find dependable parameter estimates, the dependent variable CI has been log-transformed. The new variable i.e. LnCI satisfies the OLS assumptions. Another point with regard to this estimation is that four outlier cases were detected on the criterion of standardized residual value lying outside the range \pm 3 . These cases therefore have been deleted from the regression analysis. The OLS estimation results have been produced in Table 3 . The result shows that overall the model has a good fit with $\mathrm{F}(7,151)=$ 13.41 having $\mathrm{p}$-value $<0.0001$. The $\mathrm{R}$-square value of the regression is 0.2496 . Moreover, in order to avoid possible multicollinearity problem VIF values have been calculated for each of the regressors included in the model. The mean VIF of the regressors is 1.27, with VIF of individual regressors being less than 1.50 . Heteroscedasticity has been tested using Breusch-Pagan test, which has rejected the homoscedasticity assumption, and hence robust standard errors are calculated.

The principal variable of interest i.e. FPHD is found statistically significant with p-value less than 0.01 , and it is found to affect cropping intensity positively. Higher cropping intensity of the flood prone cultivator households, however, may be attributed mainly to their subsistence agriculture and is mainly due to flood induced crop damages. In the survey, it was seen that flood prone households grow rice crop in their lands regardless of the damages caused by flood during monsoon. Besides, they have to do cultivation in off-monsoon periods too, particularly the staple food crop, that is, rice, to compensate for losses in monsoon. People are generally seen to grow traditional rice varieties during both the monsoon and the off-monsoon periods which are often damaged by floods, and characterised by lower productivity. While the traditional Kharif rice varieties, locally known as Sali, requires multiple transplantations due to damages, the autumn rice varieties - locally known as $A h u$ - are also subject to damages by the early monsoon floods during their ripening and harvesting time. On the other hand, short maturing rice varieties are seldom grown by the locales, either due to unavailability or high cost of the seeds, lack of irrigation facilities, or due to lack of awareness about them. Flood prone people are also seen to grow non-rice autumn crops to add to their agricultural income to sustain their subsistence livings, thus contributing to a higher cropping intensity by these farmers. Flood free people, on the other hand, are mostly seen to grow Sali rice varieties only, thus manifesting a lower cropping intensity.

The variable DEP is positivity associated with the dependent variable LnCI, implying that higher the value of DEP, higher will be the LnCI. This may be due to more supply of labour from dependants - children or aged required for agricultural activities. This type of labour engagement in agriculture sector is very common to rural areas. Besides, larger proportion of the dependant members may induce the households for intensive cultivation to meet its diverse needs, requiring multiple cropping or seasons. Large number of dependants may also necessitate the non-dependant members, in the absence of non-farm work opportunities, to engage in cultivation and to generate more income from it to support their household. This leads to higher cropping intensity of the households with higher dependency ratio.

Table 3: OLS regression result of Log of Cropping Intensity (LnCI)

\begin{tabular}{|c|c|c|c|c|}
\hline Predictor Variable & $\begin{array}{c}\text { Coefficient } \\
\text { Estimates (B) }\end{array}$ & Robust Std. Error & t-value & $\mathrm{p}>|\mathrm{t}|$ \\
\hline FPHD & .2253438 & .0771641 & 2.92 & $0.004^{* * *}$ \\
\hline DEP & .0813772 & .0450119 & 1.81 & $0.073^{*}$ \\
\hline HS & .0207391 & .0149562 & 1.39 & 0.168 \\
\hline FS & -.0268145 & .0053869 & -4.98 & $0.000^{* * *}$ \\
\hline HI_EDU & .0635999 & .0290335 & 2.19 & $0.030^{* *}$ \\
\hline FARM & .0611448 & .0764438 & 0.80 & 0.425 \\
\hline SHARE_CROP & -.4931502 & .0767628 & -6.42 & $0.000^{* * *}$ \\
\hline CONSTANT & 4.633777 & .1518763 & 30.51 & 0.000 \\
\hline
\end{tabular}

Source: Author's estimation based on the field survey data; Note: *,**, *** significant at $10 \%, 5 \%$ and $1 \%$ 
level of significance respectively; Dependent variable: Logarithm of cropping intensity (LnCI); Model: Linear $(\mathrm{OLS})$; No. of observations $=159 ; \mathrm{F}(7,151)=13.41 ;$ Prob $>\mathrm{F}=0.0000 ;$ R-squared $=0.2496$; Root MSE $=$ 0.36965

Farm size (FS), on the other hand, is negatively associated with LnCI which means that larger the farm size, smaller is the cropping intensity. Given other things, a small FS may necessitate a household to practise multiple cropping in the same plot of land just to support its livelihood or for accumulative purpose of generating more income. Thus, larger FS is more likely to be associated with a lower cropping intensity, holding for other variables. The result also shows that the cultivator households who did only sharecropping during the preceding year, on the average, have lower cropping intensity as compared to the other households. This is due to the fact that in the study area sharecropping is done mainly for rice cultivation during summer season, while in the remaining parts of the year the lands stay unused.

\section{Conclusion and Policy Implications}

The study finds that the flood prone cultivator households have, on the average, higher cropping intensity as compared to the flood free households. This, however, in no way predicts a larger agricultural output or productivity in the flood prone areas; rather the cropping activities of these households are subject to the gamble of the monsoon. With no irrigation facilities accessible to these households, the poor farmers cannot take the risk of growing crops in the off monsoon periods which is also, to a greater extent, hindered by lack of access to greater market for the non-rice crops that they could have grown during the winter or autumn seasons in particular. The results, therefore, inherently prescribe for a comprehensive agricultural policy particularly designed for flood prone areas, enveloping strategies but not limited to suitable irrigation infrastructure, mass awareness for better agricultural practices, subsidised seeds and other inputs, and post harvest agriculture infrastructures including marketing facilities. Further, there is a need for extensive research works on the types and viability of adaptation measures, if any, in the study area and thereby to suggest the suitable ones for an improved and sustainable agriculture based livelihoods of people.

\section{Disclaimer:}

The paper is based on the author's PhD thesis titled Flood and Socio-Economic Livelihoods of People in Dhemaji District of Assam submitted to Gauhati University, Assam, in 2017. The usual disclaimer, however, applies.

\section{References:}

[1]. Bhattacharyya, A. and M. Werz (2012) 'Climate Change, Migration, and Conflict in South Asia: Rising Tensions and Policy Options across the Subcontinent : Rising Tensions and Policy Options across the Subcontinent, Centre for American Progress, Retrieved from:

https://cdn.americanprogress.org/wp-content/uploads/2012/11/ClimateMigrationSubContinentReport_small.pdf accessed on $1 / 4 / 2017$

[2]. Calder, I.R., Aylward, B. (2006) Forest and Floods: Moving to an Evidence-based Approach to Watershed and Integrated Flood Management, Water International, 31(1) March

[3]. Charles, S. (2011) Climate Change: Impacts on Food Safety, Natural Resources \& Environment, 26(1), 44-47

[4]. Dekens, J. \& M. Eriksson (2009) 'Adapting to Climate-induced Water Stresses and Hazards in the Hindu KushHimalayas', Sustainable Mountain Development No. 56, ICIMOD, Winter, 2009

[5]. FAO (2007): 'Adaptation to Climate Change in Agriculture, Forestry and Fisheries: Perspective, Framework and Priorities', Rome, Italy

[6]. FAO (2008) 'Climate Change Adaptation and Mitigation in the Food and Agriculture Sector', Technical Background Document, Rome [retrieved from ftp://ftp.fao.org/docrep/fao/meeting/013/ai782e.pdf on 1/2/2017 ]

[7]. Government of Assam (2014): Assam Human Development Report, 2014, Planning and Development Department

[8]. Howden, S. Mark; Jean-François Soussana, Francesco N. Tubiello, Netra Chhetri,Michael Dunlop and Holger Meinke (2007) 'Adapting Agriculture to Climate Change', Proceedings of the National Academy of Sciences of the United States of America, Vol. 104, No. 50 (Dec. 11, 2007), pp. 19691-19696

[9]. Nelson, C., Mark W. Rosegrant, Jawoo Koo, Richard Robertson, Timothy Sulser, Tingju Zhu, Claudia Ringler, Siwa Msangi, Amanda Palazzo, Miroslav Batka, Marilia Magalhaes, Rowena Valmonte-Santos, Mandy Ewing, and David Lee (2009) 'Climate Change: Impact on Agriculture and Costs of Adaptation', Food Policy Report, International Food Policy Research Institute, Washington D.C.

[10]. WHO (2002) 'Floods: Climate Change and Adaptation Strategies for Human Health', Report on a WHO meeting, London, United Kingdom 30 June - 2 July 2002

Retrieved from http://www.euro.who.int/_data/assets/pdf_file/0007/74734/E77096.pdf [Accessed on 1/2/2015] 